UDC 821.112.2.09 Kafka F.

https://doi.org/10.18485/ms_zmskij.2020.68.1.9

Мср Катарина Н. Пантовић

\title{
КАФКИНА МИКРОПРОЗА КАО ПЕСМА У ПРОЗИ*
}

\begin{abstract}
У раду настојимо да покажемо да се кратке прозне форме које је писао Франц Кафка (1883-1924) могу сврстати не само у традиционалне прозне категорије попут приповетке, новеле, кратке приче, већ и скице, параболе, арабеске, па и песме у прози. За поступак поетизације прозног ткива, као и за разбијање традиционалне наративне поставке прозног текста, од кључне су важности инйросиекиија и протагониста - лирски субјекй, односно његово конституисање и релације према другим лицима или предметном свету. Иако Кафкина микропроза читаоца увек ставља пред својеврсну загонетку тумачења, усредсређујемо се на појединачне текстове и анализирамо поменуте елементе.

Кључне речи: Кафка, микропроза, песма у прози, прозаида, жанровска амбивалентност.
\end{abstract}

Амбивалентост књижевног жанра песме у прози (енг. prose poem) као двоструке родовске фигуре одувек је истицана у књижевној теорији (S. Bernard, J. Hauck, D. Lehnmann, N. Santilli, Б. Стојановић Пантовић), а премда је матична земља контитуисања песме у прози и њеног „озваничења“ као књижевног жанра Француска, односно, француска књижевност, своје упориште пронашла је и у другим литерарним традицијама, пре свега у немачкој и америчкој. Иако сама структурна и семантичка природа песме у прози налаже хибридност, амбивалентост, те ју је, стога, тешко подвргнути строгом дефинисању и књижевно-теоријском утемељењу, у главним цртама она се може означити као „кратак састав (фрагмент, микроцелина) која се од лирике пре свега разликује по спољашњој форми, која је најближа ритмичкој и лирској прози. Њен основни израз није стих, већ исказ, односно реченица“ (СтолАновић ПАнтовић 2012: 13). Од прозних елемената које садржи, поред

* Рад је настао за потребе курса Дискурс иессме у йрози на мастер студијама на Одсеку за компаративну књижевност са теоријом књижевности Универзитета у Новом Саду под менторством доц. др Соње Веселиновић. 
реченице, често је свакако развијена наративна ситуација, јер „прича настаје једино путем наративизације“" (АБот 2009: 49).

У погледу дужине, песма у прози или прозаида креће се у распону од сасвим кратког фрагмента, до текста дужине странице или две. Њена веза с поезијом, с друге стране, препознаје се по присуству бројних реторичких поступака и фигура (лајтмотив, синтаксички паралелизми, реторска питања, тропи итд) (СтојАНовић ПАНтовић 2012: 13). Песму у прози одликује, у том смислу, преузимање различитих жанровских идентитета, те ваља нагласити актуелна разумевања овог жанра као својеврсног дискурса проистеклог из процеса прекорачења граница поетског, односно прозног језика. Овиме се ствара један посебан, хибридни дискурзивни универзум, те не треба да чуди приближавање, а каткада и изједначавање песме у прози са другим кратким прозним врстама какве су, на пример, цртица, запис, парабола, кратка прича, анегдота итд.

Управо у овим граничним прозним жанровима огледао се Франц Кафка (1883-1924) који је, поред романа и приповедака, писао кратке приче, параболе и сновидне (traumhaft) записе који су остали забележени у његовим Дневницима и писмима (Писма Милени, Писмо оиу итд). За експресионистички покре ${ }^{1}$ у целини битно је брисање граница између појединих жанрова, особито када је реч о кратким прозним врстама (ANZ 2002: 186-187), док су проучаваоци Кафкиног дела одавно нагласили да је удео лирског у његовој прози, нарочито краткој, изузетно доминантан (KURZ 195: 343-347). Стога се његови текстови могу сврстати не само у традиционалне прозне категорије попут приповетке, новеле, кратке приче, већ и скице, параболе, арабеске, мисаоне бајке, па и песме у прози. Поетизацији прозног ткива, као и разбијању традиционалне наративне поставке прозног текста, узрок умногоме лежи у утицају снова на Кафкину приповедачку уметност. У не малом броју његових наратива присутна је симулација механизма снова која подразумева алогичност и акаузалност, што је свакако повезано са психоанализом несвесног и надреалистичким дискурсом (ANZ 2001: 187). Кафкина микропроза, тако, читаоца увек ставља пред својеврсну загонетку тумачења, јер не постоје конкретни генерички показатељи који ће овај хетерогени жанр поуздано идентификовати, да би се самим тим могао успоставити и систематизовати известан хоризонт очекивања (НAUCK 1994: 8). Кафкина проза, уопште узев, као да намерно избегава могућност интерпретације, а његов јунак изнова покушава да оправда своје постојање на овом свету, да се у њему усредишти; док остаје нејасно којој то инстанци Кафка, односно његови протагонисти, непрекидно осећају потребу да се оправдају и бране.

Издвајање и ослобађање фрагмента из некада целовитог текста потпомогло је обликовање и даљи развој песме у прози као засебне (микро)целине

\footnotetext{
${ }^{1}$ Премда хронолошки и поетички припада најпре експресионистичком покрету, Кафкина проза садржи елементе и других поетичких система и стога га је незахвално везати искључиво за један правац, односно стилско усмерење.
} 
(СтолАновић ПАнтовић 2012: 10), а ова појава нарочито је подстицајна када је разматрање Кафкине прозе у питању, јер су поједини фрагменти из његових романа, некад и поглавља, третирани као засебне (кратке) приче - то је, рецимо, случај са параболом Пред законом из романа Процес. У Кафкиним кратким причама фрагмент функционише као тоталитет за себе и има предност у односу на целовит, континуиран текст. Искуство свакодневице је индивидуализовано на посебан начин, јер његова проза избегава све што је наглашено, патетично, осећајно, непосредно изречено и психолошки продубљено. Уместо тога, овај стил је једноставан, јасан, трезвен и са некад застрашујућом оштрином и равнодушношћу оцртава психичка збивања. У теорији књижевности често се говори о „кафкијански срезаним причама“, које подразумевају „строгу композицију што уступа место намерној уметничкој недовршености и неизвесности““ (БАшчАРЕВић 2016: 419), док израз „кафкијански“ одмах у мисли позива „слику малог, безименог човека заробљеног у егзистенцијалном кошмару из ког нема излаза ни буђења“ (ЖмегАч 1982: 82), односно „нарочиту стрепњу, страх, неизвесност и ужас“ (СтоЈАновић ПАнтовић 2012: 134). То, дакле, нису чврсте, затворене форме, већ поседују отворен завршетак и велику способност наговештаја, што Снежана Башчаревић у свом раду Кафкини мали нарайиви као ойворене йараболе оцењује као спону између традиције и иновације, односно приповедне прозе двадесетог столећа насупрот отвореним параболама чија су значења подложна различитим тумачењима (2016: 20).

Ово, међутим, не значи да дијалог са сопством и интроспекција у класичном смислу нису присутни. Рекло би се, штавише, да су опхрваност властитим мислима и покушај смештања себе у егзистенцијалном поретку више заступљени управо у микропричама, односно песмама у прози, него у романима - тим пре што је највећи број Кафкиних микронаратива предочен у првом лицу. Интроспекција се у његовим прозаидама јавља најчешће посредована неким запажањем, одакле и почиње дискурзивно кретање. Предмет опажања може бити подстицај спољашње или унутрашње природе, па некад управо и рефлексија из чега се, путем аналогија и евокације, отварају нови слојеви искуства који текст одводе у асоцијативном правцу. Премда је Кафкина заоставштина прича обимна, предмет наше анализе биће само поједине кратке прозаиде, микронаративи, дуги не више од једног или два пасуса. Ови микротекстови фигурирају као својеврстан језички корелатив неке експресионистичке слике у којој је косина, на брзину осмотрена или промишљена појава, иманентни део представљеног предмета (уп. ЈANTZ 1998: 24). Ово ће бити показано на примеру седам прозаида, од којих би се четири могле сврстати у корпус „градских“ прозаида јер се Субјектово искуство генерише непосредно самим бивањем у градској средини (Прозор на улииу, На йоврайку у дом, Пуйник у йрамвају, Окани се), а остале три би се могле назвати „параболичним“ прозаидама јер у њима Кафка конструише текст на подлози жанровских конвенција басне, специфичне форме приповедања. Некад је то сасвим дословно (Мала басна, О йараболама), а некад 
структура параболе служи само као олабављена форма за изрицање садржаја који код Кафке увек поседује некакав филозофски или метафизички предзнак (Полазак).

Протагониста Кафкиних прозаида најчешће је напуштен, самотан „матори момак“" који повремено задовољство налази у сусрету са пријатељима. Преносимо прозаиду Прозор на улииу у целости:

Ко живи напуштен, а ипак би с времена на време желео да негде нађе друштво, ко с обзиром на промене дневних часова, временских, пословних и сличних прилика неизоставно жели да види било коју руку, за коју би се могао ухватити - тај неће моћи дуго издржати без прозора који гледа на улицу. А ако је са њим баш тако да ништа не тражи, него само као уморан човек, дижући и спуштајући очи између публике и неба, прилази прозору, мада то не жели, и мало забацује главу - ипак ће га коњи доле повући у поворку кола и буке, и тиме, коначно, ка људској слози (КАФКА 1984: 56).

Центрипетална усредсређеност мале форме на једну ситуацију, односно на једног јунака и једно преовлађујуће осећање, са наоко недовршеним, прозаичним, једноставним, али вишезначним крајем, основна је „поставка“ Кафкиних прозаида. Радња ове прозаиде, као и наредних које ће бити анализиране, одвија се у наизглед смиреној атмосфери свакодневице у којој прозни субјект трезвено и контролисано проговара о стварности, односно о самоћи. Премда је прозаида изречена у замишљеном трећем лицу, њени искази се пре свега односе на аутоперцепцију (он „диже и спушта очи између публике и неба“ и „мало забацује главу“). Субјект изриче тврдњу да „ко живи напуштен, (...) неће моћи дуго издржати без прозора који гледа на улицу“. Овакво саветовање, коментарисање, препоручивање некакве радње у прећутном дијалогу одају утисак протагонисте који у потпуности схвата општи поредак ствари и свет доживљава као претерано јасан и без тајни, те се јавља са зрелим опсервацијама. То дубље познавање предметног, усамљеничког људског, али чак и животињског света, сугерисано је у многим другим Кафкиним кратким и дужим наративима (Пролазници који тирче,

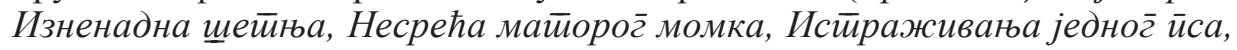
Преображај итд). Коментарисање, међутим, као нарочит наратолошки поступак сугерише две ствари: пре свега, тобожњу дистанцу између говорне инстанце/јунака и приповеданог; а друго, оно се готово увек односи на генерализације, тезе, гноме које неодређена говорна инстанца може мање или више неутрално да саопшти. Целим овим трезвеним исказом провејава пак утишана људска топлина која бива загушена и ућуткана субјектовом егзистенцијалном стрепњом, а чији се модуси протежу од осећаја резигнираности па до потпуне конфузије својом позицијом у овом свету (као што је случај у прозаиди Пуйник у тирамвају). Ово је дискретно наглашено са неколико детаља који се могу подвести готово под тактилне, чулне слике, као што је, на пример, додир људске руке за коју би се јунак чежњиво желео 
ухватити, или уморно, успорено забацивање главе, као, уосталом, и сама појава нужности прозора на улицу ради посматрања других пролазника који хитају градом, односно, живота који се одиграва под њим. Управо се доле, на тлу, на асфалту, конструише сав живот, врева града, коња и кола, и на крају „људска слога“, које субјект из своје контрапозиције „напуштеног“ (не чак ни самог, већ напуштеног!), изолованог од додира са другим особама, и самог у стану посматра с висине, с прозора.

На йоврайку у дом, такође једна од прозаида чија се радња одвија у урбаном амбијенту, почиње несвакидашњим ускликом: „Погледајте колику снагу убеђивања има ваздух после олује! Јављају ми се моје заслуге и савлађују ме, иако се ја не опирем“ (КАФКА 1984: 61). Какве се то заслуге јављају прозном јунаку? „Ја сам с правом одговоран за све ударце о врата, по плочама столова, за све здравице, за љубавне парове у постељама, међу скелама новоградњи, стиснуте уза зидове кућа у мрачним уличицама, на отоманима у борделима“ (КАФКА 1984: 61). Рекло би се да ови искази поседују поједине нелогичности премда је исказ, започет из самог центра збивања, сажет и предочен лапидарно. Зашто би заслуге, које обично поседују позитиван предзнак, опседале и савлађивале јунака? Зашто им се јунак препушта и не покушава да се опире? Заслуге у овом контексту као да пре означавају кривицу, појам толико чест код Кафке, јер он себе терети као одговорног за све добро и све лоше што се у свету, у том граду дешава; речју, он себе налази одговорним за цео живот који је метонимијски предочен кроз визуелно подстицајне слике и детаље из свакодневице, просечног живота. Он постаје једно са градом, и територија над којом има превласт градацијски бива увећана, а анафорско понављање заменице „ова“ доприноси ритмичности исказа: „Корачам, и мој темпо је темпо ове уличне стране, ове улице, ове четврти“. Ваздух после олује утиче на субјекта тако да постаје евокативни окидач за распламсавање интроспекције и сагледавање читавог свог живота: „Одмеравам сопствену прошлост и будућност, али налазим да су и једна и друга изврсне, ни једној ни другој не могу дати преимућство, и једино морам да корим неправичност провиђења, које ми толико иде наруку“" (КАФКА 1984: 61). Као што је већ наглашено, интроспекција се у Кафкиним прозаидама јавља најчешће посредована неким запажањем, одакле и почиње дискурзивно кретање. Из почетних рефлексија се, путем аналогија и евокациje, отварају нови слојеви искуства који мисаони ток одводе у асоцијативном правцу. Кафкин јунак, премда му све иде како треба, није задовољан својом ничим укаљаном прошлошћу, а ни будућношћу (не садашњошћу! већ будућношћу) коју тако самоуверено пророчки означава савршеном. Он, штавише, усуд назива „неправичним“ јер му „све иде наруку“. Овај парадокс представља per excellence кафкијански гест, који би у овом контекту могао бити тумачен и као израз иронијског обраћања самом себи.

Почетна грандоманија и осећај света свепрожетог собом у последњем пасусу сплашњава, када се и открива право лице кафкијанског јунака: суштински немоћан човек који се непрестано труди да схвати шта се од њега 
тражи, који је његов положај у свету, и настоји да објасни јединствену људску природу која се одупире сваком растављању и систематизовању. У овој прозаиди то је тек назначено и сугерисано једном изненадном (вероватно тескобном) мисли која је јунаков ум окрзнула док се пењао уз степенице, недовољно да би умео да је артикулише, али довољно да би се накратко мистериозно замислио: „Само кад улазим у своју собу, само онда постајем малчице замишљен, мада не могу рећи да сам се за време пењања уза степенице сетио нечег о чему би вредело размишљати. Не помаже ми много што широм отварам прозор и што у једној башти још свира музика“" (КАФКА 1984: 61). Иако „не може да се сети нечег о чему би вредело размишљати“, субјект ипак, изгледа, покушава да у мислима реконструише или макар призове мисао чији је одбљесак ухватио, јер га музичка врева из баште под прозором омета у томе. Као и у прозаиди Прозор на улииу, прозор и овде постаје дословни прозор у архитектонском смислу, али и прозор у свет, подсећање на живот који се одвија мимо појединчеве контроле.

Непрекидно спорење са самим собом (и са имплицитним сабеседницима) заступљено је и у дескриптивној прозаиди Пуйник у тирамвају. Она је, такође, у првом лицу, и почиње in medias res: „Стојим на платформи електричног трамваја, и потпуно сам несигуран у погледу свог положаја на овом свету, у овом граду, у својој породици. Чак ни узгред не бих умео рећи какве бих захтеве у било ком смислу могао с правом да поставим“ (КАФКА 1984: 63). Он покушава да оправда своје постојање у овом свету и да се одбрани: „Не могу се ничим бранити што стојим на овој платформи, што се држим за ову ручицу, што допуштам да ме носи овај трамвај, што се људи склањају пред њим или иду мирно, или се одмарају пред излозима““ (КАФКА 1984: 63). Набрајање, поново, умногоме утиче на повећање ритмичности текста. Слике из живота око њега се у готово калеидоскопском маниру смењују пред очима, и јунакова способност опсервације равна је оку камере које прати различите визуелне, тактилне и аудитивне надражаје из непосредне близине. То се односи и на наредни пасус који у текст уводи другу фигуру, девојку из трамваја, чији је физички изглед дочаран једноставно и прилично дословно, али са изузетним нагласком на детаљима:

Трамвај се приближава станици, једна девојка стаје близу врата, спремна да сиђе. Видим је тако јасно као да сам је опипао. Одевена је у црно, набори на сукњи се готово не померају, блуза јој је припијена уз тело и има оковратник од беле густе чипке, отвореном левом шаком се ослонила о зид, кишобран у њеној десној руци дотиче други степеник одозго. Лице јој је преплануло, а нос, лако стањен у средини, при врху је округао и широк. Има много смеђе косе и лелујаве кратке власи на десној слепоочници. Мало ухо јој је приљубљено уз главу, али ја стојим близу и видим целу полеђину десне ушне шкољке и сенку при корену (КАФКА 1984: 63).

Овакав нагласак на уочавању наоко неважних детаља карактеристичан је за већину Кафкиних микронаратива. Ови детаљи заокупљају пажњу по- 
сматрача који из перспективе првог лица започиње неку врсту регистровања и описивања властитог психичког стања, као и објеката из своје непосредне близине (девојка), а затим изненада прекине метонимијски ланац мотивских јединица (СтолАновић ПАнтовић: 59) и нагло поентира, у овом случају реторским питањем: „Упитао сам се онда: Како то да се она не чуди себи, да држи уста затворена и не казује ништа о томе?“ (КАФКА 1984: 63).

Његовој упитаности и замишљености ништа не може да промакне и сваки спољни надражај или сећање на прошлост дозивају мисли које субјект рационално распоређује у свом уму. Он, међутим, уједно не производи никакво позитивно искуство јер не успева да пронађе коначно упориште мишљења. Увек присутна метапоетска димензија опомиње на траг неизреченог, недосегнутог, које се само наслућује и пригушено проживљава у својој трансцендентној празнини. Упркос наизглед стабилној позицији, Кафкин субјект ипак настоји да се усредишти у површном, отуђеном и амбивалентном свету који одише тескобом. То је случај и са прозаидом Окани се која изазива многобројна филозофско-религиозна тумачења. Њу такође преносимо у целости:

Било је сасвим рано јутро, улице чисте и пусте, ишао сам на станицу. Кад сам упоредио сат на једном торњу са својим часовником, видео сам да је много касније него што сам мислио, морао сам веома похитати, страх због тога открића поколебао ме је којим правцем да кренем, још нисам сасвим добро познавао овај град, но срећом, у близини је био неки стражар и ја му притрчах и задихано га упитах којим путем треба да идем. Он се осмехну и рече: „Ти би да сазнаш пут?“, „Да“, одговорих, „пошто га сам не могу пронаћи“. „Окани се тога, окани се“, рече он и окрете се снажним замахом, као људи који желе да остану сами са својим осмехом (КАФКА 1984: 401).

Ова прозаида одише тескобом и злослутношћу на више равни: најпре је сам наративни темпо убрзан због лапидарног казивања и ужурбане атмосфере у којој се субјект налази. Он је у журби, улице су пусте, не познаје довољно добро град којим се креће и, поврх свега, схвата да му сат много касни. Важно је истаћи да реакција стражара у овој прозаиди умногоме подсећа на одговоре вратара из параболе Пред законом из романа Процес. Пред законом стоји вратар и њему долази човек са села који га моли да га уведе у закон, али вратар то одбија, рекавши да му сада не може одобрити приступ. Сељак проведе године и године чекајући на улазу у закон, у покушајима да приволи вратара да га пусти:

Пред смрт у његовој се глави скупљају сва искуства читавог тог

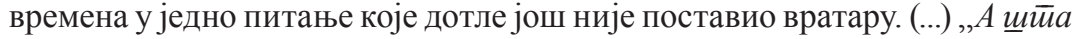
би јоми хйео да знащи?" - упита вратар - „,ии си незајажљив". „Кад сви теже закону“, рече човек, „како је онда могуће да за све ове године нико није тражио улаз сем мене?“"Вратар увиђа да је човеку дошао крај, и да 
би га овај још чуо слухом који већ замире, продере се на њега: „Овде нико други није могао добити приступ, јер је овај улаз био одређен само за тебе. А сада идем да г̄a зайворим“ (КАфКА 1990: 281, курзив К. П.).

Недвосмислено егзистенцијални и филозофски импулс ових фрагмената лежи у субјектовом (односно, сељаковом) напору да стигне до циља, да у симболичком смислу допре до истине, смисла, и у апсолутној и a priori немогућности и његовој онемогућености да у томе успе. Премда је подстицајна значењска поливалентност коју овакви микронаративи поседују, једно је сигурно: кафкијанским јунацима непрестано измиче истина у тренутку када покушавају да је формулишу или су на путу да до ње допру. Таква проза смера на полемику, непомирљивост, прећутни дијалог са читаоцем при чему аутор жели да буде једини партнер у разговору (уп. БАшчАРЕВић: 423). Јунак у прозаиди Окани се, као и сељак у параболи, бивају спречени да дођу до истине намерно, грубо и из нејасних разлога. Код јунака се, међутим, издваја једна друга особина, која умногоме одређује основни тон Кафкине прозе уопште. То је интуиција, алогична способност која се манифестује наизглед неутемељеним страхом, сумњом и стрепњом. Кафкини јунаци подбацују у комуникацији са својим окружењем, иако су и реакције стражара наизглед немотивисане. Овиме аутор потцртава својеврсни прометејски, сизифовски положај човека у свету, те се ови текстови могу тумачити и кроз митску симболику, којој је Кафка у многим причама итекако био наклоњен. ${ }^{2}$

Када су „параболичне“ прозаиде у питању, вреди најпре напоменути да поједини критичари вреднују целокупно Кафкино дело као екстензивну и отворену параболу (уп. БАшчАРЕвић: 419). Џозеф Стрелка (Joseph P. Strelka) у свом раду Kafkaesque elements in Kafka's novels and in contemporary narrative prose издваја неколико кључних особина које обележавају Кафкину прозу, наглашавајући да аутор исеца све непотребне језичке украсе и усредсређује се само на оно кључно у људској ситуацији (STRELKA 1985: 169). Као најважнију карактеристику, пак, издваја то да у Кафкином делу ништа не треба схватати дословно, већ пре као параболу: „Ако Кафкини наративи нису примери просте, класичне форме параболске фикције, они су неминовно параболски наративи комплексније и слојевитије природе и могли би се назвати симболичке йараболе“"3 (STRELKA: 172). То су истовремено, свакако, параболе парадокса, који је код Кафке образац представљања апсурдног пејзажа и повезан је са оним што је у теорији називано „бесконачном амби-

2 Погледати текст: Rolf J. Göbel: Selbstauflösung der Mythologie in Kafkas Kurzprosa.

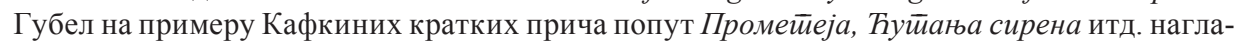
шава Кафкину скепсу према устаљеном разумевању мита у модерни, и показује како Кафка изводи ,преправке“ митова. Он, заправо, подрива мит, демонстрира како је он током времена изгубио смисао услед превеликог броја тумачења и верзија. У Кафкином прозном универзуму, митски јунаци су, парадоксално, прогнани из сопствених митова деловањем историје.

3 Превод је наш. 
валенцијом“ (the infinite ambivalence) (StrelKA: 172, према: Wilhelm Emrich: „Die unendliche Ambivalenz Franz Kafkas“, in Polemik, Frankfurt am Main: 1968). Исто тако, док је стил „градских“ микронаратива заснован на паратакси, симултаном кинематографском повезивању исказа, и већем степену непосредне интроспекције и ауторефлексије, код друге групе реч је о параболичном, „објективном“ стилу чија структура и смисао готово да наводе читаоца на својеврсно решавање задатка. ${ }^{4}$

Погледајмо параболу Мала басна, која се састоји из свега неколико реченица и представља дијалошку сцену:

„Ах“, рече миш, „свет се сваког дана све више сужава. Испрва је био толико широк да ме је било страх; трчао сам и трчао, и осетио се толико срећан кад сам најзад десно и лево у даљини видео зидове; али ти дугачки зидови толико брзо хитају један ка другоме да се ја налазим већ у последњој соби, а онде у углу чека клопка у коју ћу утрчати.“ „Треба само да промениш правац трчања“, рече мачка и поједе га (КАфКА 1984: 337).

Кафкин „параболични наративни стил“ како га Зокел (Sokel) означава, уобличен је у овој модерној параболи (којој, иначе, није Кафка дао назив, већ Макс Брод). Аутор конструише текст на подлози жанровских конвенциja басне, у којој су јунаци животиње, и чији је смисао у разрешењу, односно поуци на крају. Дијалог између миша и мачке, међутим, добија одлике парадоксалног, апсурдног и иронијског говора, а неочекивани обрт лежи нарочито у мачкиној реплици која усмерава текст у другачијем правцу од очекиваног. Изузетно визуелно подстицајне слике зидова који се сужавају и клопке која га чека у углу последње собе, на крају пута, у читаоцу изазивају тескобно, злослутно осећање. Мишева агорафобија се, тако, преображава ненадано у својеврну клаустрофобију; испрва страх од ширине, слободе, неограничености резултује страхом од краја и сужених зидова. Фридрих Немец (Friedrich Nemec) у својој студији Kafka-Kritik (1981), а у поглављу Алиеернайиве йройастии: Мала басна (Die Alternativen des Scheiterns: Kleine Fabel) истиче да се кроз лик мачке читаоцу показује да је разум (Vernunft) онај који образује неминовни пут природне селекције по принципу „појести или бити поједен“" (zu fressen oder gefressen zu werden) (NEMEC 1981: 13). У том смислу, миш је онај који је ирационалан, он је увек пометен осећањем страха због којег и бежи од ширина и безглаво завршава у уском простору. Стога и овај лаконски завршетак басне поседује истоветну објективну, готово аутоматску артифицијелну прецизност (die gleiche sachlich-automatenhafte Präzision), који чак и не делује у потпуности цинично, већ пре као једноставни, самоподразумевајући, равнодушни савет (NEMEC: 15). Парадокс у овој параболи лежи још више у томе што мишева смрт не даје никакво морално разрешење: односно, до тог моралног разрешења или поуке није једноставно

${ }^{4}$ О томе код: Walter Sokel, „Die Prosa des Expressionismus“, u: W. Rothe, Expressionismus als Literatur. Gessamelte Studien, Bern-Muenchen, 1969, 157-169. 
доћи. Може се говорити и о „својеврсном инфантилизму и анегдотском поступку, као и о нултом крају“ (СтолАновић ПАнтовић: 59). Кафка у свом делу не успоставља психолошки продубљен и логичан свет, већ акаузалан и свет без присуства мотивације. Тако је и у Малој басни, иако се аутор у формалном смислу придржава класичне поставке басне у којој је слика света рационално структурисана. Форма ове басне подражава класичну басну, међутим, њен садржај и суштинско значење, заправо, изневеравају и подривају овај прозни жанр.

Миш је, као и све Кафкине фигуре, представљен у узалудном трагању, вртењу у круг у потрази за смислом, што, свакако, може бити симбол модерног света и безизлазности егзистенције, симбол дубоког расцепа између субјекта и спољњег света. Између понашања ликова и разлога за такво њихово понашање, додуше, не постоји готово никаква веза, и оно се не може окарактерисати као логично или каузално. Слично је и у параболи семантички и симболички слојевитог наслова Полазак:

Наредио сам да ми изведу коња из штале. Слуга ме није разумео. Сам сам отишао у шталу, оседлао коња и узјахао га. Чуо сам како у даљини свира труба, па упитах слугу шта то значи. Он нити је што знао нити је што чуо. На капији ме је зауставио и упитао: „Куда јашеш, господару?“ - „Не знам“, рекох, „само даље одавде, само даље одавде. Непрестано све даље одавде, само на тај начин могу стићи до свога циља.“ „Ти, дакле, знаш свој циљ?““, упита он. „Знам““, одговорих, „па рекао сам: 'Даље одавде’, то ми је циљ.“ „Ниси понео храну“, рече он. „Не треба ми“, одвратих, ,путовање је толико дуго да ћу умрети од глади ако уз пут ништа не добијем. Никаква понесена храна не може ме спасти. То је, на сву срећу, заиста огромно путовање““ (КАФКА 1984: 342).

Теодор Адорно (Theodor W. Adorno) назвао је Кафку „параболичарем непродорности“ („Paraboliker der Undurchdringlichkeit“), а непродорност се у овом смислу односи најпре на неизрециво, неразумљиво, херметично. У овој прозаиди наизглед је све израз непомућене, очигледне стварности, субјект је предочен кроз крте контуре, а дискурс који генерише је једноставан, на моменте и баналан, али немушт, непрецизан, вишезначан. Код Кафке свет је састављен од неколико равни: сновидне, лавиринтске и ,реалистичне“, и ови елементи се непрестано сударају у једној неизбежној „стварности“, а у овој прозаиди речи Даље одавде као да имају функцију некаквог рефрена, или лајтмотива, јер их господар понавља четири пута. Ако пажљивије погледамо, увидећемо да је она састављена од парадоксалних, апсурдних исказа, односно јединица којима мањка узрочно-последичности и логичности, а које поткрепљују тезу о немости Кафкиних јунака и неспособности за комуникацију: 1. слуга не разуме једноставан господарев захтев да треба да изведе коња из штале; 2. слуга не чује звуке трубе у даљини које чује господар; 3. господар на питање где се упутио, испрва даје одговор „не знам“, а затим „што даље одавде“; 4. иако не зна тачно куда се упутио, тврди да 
му је то и циљ; 5. господар не носи храну на пут, иако саопштава да је пут толико дуг да ће сигурно умрети од глади; 6. никаква понесена храна га не може спасити, једино она коју (и ако) добије током самог пута; 7. господар употребљава апсурдан израз у овом контексту, „на сву срећу то је заиста огромно путовање“.

Пошто Кафкина уметност доводи у питање доступност перцепције и сазнања, неминовно се ствара дисоцијација између текста и смисла. Ова дисоцијација се, међутим, ствара и између доживљеног и недоживљеног, између сновима импрегниране стварности и овоземаљског, између најтачнијег навођења детаља и напетог прикривања суштине. Оваква немуштост, шкртост при артикулацији, парадоксално, треба да обликује лагано напредовање ка властитом крају, па се, у том смислу, може рећи да је већина (ако не и све) Кафкиних парабола о животном току/путу. Њихов параболични смисао почива у сизифовском, људском напору да избегну властиту судбину с једне стране, и да је спознају с друге. Фатум ове јунаке, међутим, напослетку и често без много смисла, ипак сустиже.

Погледајмо последњу параболу која ће бити предмет анализе у овом раду, О йараболама:

Многи се жале да су речи мудраца увек само параболе и да се у свакодневном животу не могу употребити, а ми имамо само тај једини живот. Када мудрац каже: „Пређи преко“, он не мисли да треба прећи на другу страну, што би се ипак још и могло постићи кад би резултат био вредан пређеног пута, него мисли на неко легендарно Преко, на нешто што не познајемо, што ни он не може поближе да опише и што нам, према томе, овде не може бити ни од какве помоћи. Све те параболе желе, заправо, рећи само то да је непојмљиво непојмљиво - а то смо знали. Оно, међутим, са чим се свакога дана мучимо, нешто је сасвим друго.

На то ће рећи један: „Зашто се браните? Кад бисте слушали параболе и поступали како оне кажу, и сами бисте постали параболе, па се већ самим тим ослободили свакодневних мука.“

Други рече: „Кладим се да је и то парабола.“

Први рече: „Добио си.“

Други рече: „Али, на жалост, само у параболи.“ 402).

Први рече: „Не, у стварности; у параболи си изгубио“ (КАФКА 1984:

Може се рећи да је ово један од текстова који најприближније оцртавају природу Кафкиног дела у аутопоетичком смислу. Аутор готово да коментарише и појашњава властиту поетику која је оивичена вишезначношћу, метасмислом, неизрецивим, алузивним. Ова прозаида поседује дијалектички импулс у оквиру надмудривања двојице протагониста путем логички оснажених таутологија, а атмосфера у којој је дијалог предочен може се тумачити и као анегдотска. Рачвање смисла, скривеног смисла, универзалног смисла итд. који Кафкине приче тематизују овде је, такође, предочено готово 
кроз некакву логичку загонетку: више се не зна шта је у параболи, а шта није; шта је стварност, а шта није; где се стварност и парабола сусрећу а од које тачке се разилазе. Ова прозаида, а и целокупно Кафкино дело, представља Ја/Јаство као средишњи духовни контролни „орган“, који бива распарчан и разбијен нерешивошћу задатка који је пред њим. Стабилност Јаства се, тако, распада.

Гадамер (Hans-Georg Gadamer) је можда најпрецизније изнео запажања о Кафкиној прози:

In Kafka's writings, there is a mysterious feeling of strangeness which creates the impression that everything in it actually points beyond itself to something new. Interpretation seems a genuine determination of existence rather than an activity or an intention (GADAMER 1977: 71).

То у многоме објашњава и загонетан тон, којим као да се сугерише некакво друго, тајно значење које се никад не експлицира. Испоставља се да је овај хибридни жанр песме у прози изузетно погодан за оно што Кафка увек тежи да избегне: а то је да именује или дефинише предмет/објекат приповедања и мишљења, уз постизање максималног уметничког учинка на минималном текстуалном простору. Његови текстови пре остављају утисак опрезног кружења око разуђеног означитеља који не подлеже никаквој прецизној артикулацији, чиме се лирско-наративно поље шири најчешће асоцијативним путем, а текст одолева читаочевој анализи. Радње које Кафка приказује су танушне, емоције пригушене, крхке и бојажљиве, на вечитој граници између сна и разума.

\section{ИЗВОРИ}

KAFKA, Franc. Celokupne pripovetke. Branimir Živojinović (prev. s nemačkog). Beograd: Nolit, 1984.

KAFKA, Franz. Proces. Vida Županski-Pečnik (prev. s nemačkog). Beograd: BIGZ, 1990.

\section{ЦИТИРАНА ЛИТЕРАТУРА}

БАШчАРЕВић, Снежана. Кафкини мали наративи као отворене параболе. Зборник Майище срйске за књижевности и језик 64/ 2 (2016): 419-428.

Авот, H. Porter. Uvod u teoriju proze. Beograd: Službeni glasnik, 2009.

Anz, Thomas. Literatur des Expressionismus. Stuttgart - Weimar: Reclam, 2002.

Bofre, Žan. Uvod u filozofiju egzistencije. Beograd: BIGZ. 1977.

GöвeL, Rolf J. Selbst-Auflösung der Mythologie in Kafkas Kurzprosa. Kafka-Studien. Barbara Elling (hrsg.). New York - Berne - Frankfurt am Main: Peter Lang, 1985. 
Gadamer, Hans-Georg. Philosophical Hermeneutics. David E. Linge (trans. and ed.). Berkeley: University of California, 1977.

HaUCK, Johannes. Typen der französischen Prosagedicht. Zum Zusammenhang von moderner Poetik und Erfahrung. Tübingen: Günther Narr, 1994.

JANTZ, Antje. Zur Semantik dermoderner Melancholie in der Lyrik des Expressionismus. Heidelberg: Ruperecht-Karlz Univ., 1998.

Nemec, Friedrich. Kafka-Kritik: Die Kunst der Ausweglosigkeit. München: Wilhelm Fink Verlag, 1981.

Polgar, Antoine J. Blanchot‘s Impossible Kafka. Comparative Literature and Culture, 16/1, 2014.

Soкel, Walter. Die Prosa des Expressionismus. W. Rothe. Expressionismus als Literatur. Bern-München: Gesammelte Studien, 1969, 157-169.

Stojanović Pantović, Bojana. Pesma u prozi ili prozaida. Beograd: Službeni glasnik, 2012. STRELKA, Joseph P. Kafkaesque elements in Kafka's novels and in contemporary narrative prose. Kafka-Studien. Barbara Elling (hrsg.). New York - Berne - Frankfurt am Main: Peter Lang, 1985.

ŽMEGAČ, Viktor. Istina fikcije: nemački pripovedači od Thomasa Manna do Guenthera Grassa. Zagreb: Znanje, 1982.

Katarina N. Pantović

\section{KAFKA'S MICRONARRATIVES AS PROSE POEMS}

\section{Summary}

We argue that short prose forms written by Franz Kafka (1883-1924) can be seen not only in the light of traditional prose categories such as novellas or short stories, but also as a sketch, parabole, arabesque and prose poem. Introspection on one hand and the protagonist as a lyrical subject on the other emerge as crucial elements in the technique of lyrization of the prose form, as well as other literary devices that fracture the traditional narrative form. After giving a short historical and theoretical reminder of the constitution of the prose poem as a literary genre, the paper focuses on individual texts and offers a literary analysis, in full awareness that Kafka's micronarratives perpetually challenge each attempt of interpretation.

Универзитет у Новом Саду

Филозофски факултет

Докторске студије

Др Зорана Ђинђића 2, 21000 Нови Сад

katpantovic@gmail.com 